Makale türü / Article type: Araştırma / Research

\title{
Rekreatif Bir Etkinlik Olarak Turizm Cazibe Merkezi Ziyaretçilerinin Özçekim Motivasyonları
}

\author{
$* * *$

\section{Selfie Motivation of Tourism Attraction Center Visitors as a Recreational Event} \\ Seçkin Yıldız \\ Trabzon Üniversitesi, Spor Bilimleri Fakültesi, seckinyildizktu@gmail.com \\ (ORCID: 0000-0002-0717-3866) \\ Prof. Dr. Fatih Bektaş \\ Trabzon Üniversitesi, Spor Bilimleri Fakültesi, fatihbektas@ktu.edu.tr \\ (ORCID: 0000-0002-4569-4662)
}

\begin{abstract}
Özet
Teknolojinin gelişmesi ve sosyal medyanın ortaya çıkışıyla sosyal bir evrim sürecine girildiğini söylememiz yanlış olmaz. Bu sosyal evrim ihtiyaçlarımızı ve sosyal yaşantımızı olduğu gibi fotoğraflarımızı da etkiler haldedir. Günlük yaşamda yaptığımız özçekimler ve sosyal medyada paylaşma isteği yaşantımıza yön vermeye başlamıştır. Buradan hareketle bu çalışmanın amacı; Rekreatif bir etkinlik olarak turizm cazibe merkezi ziyaretçilerinin özçekim motivasyonlarının açıklanmasıdır. Literatürle desteklenen bu çalışmada araştırmanın amacına uygun olarak nitel araştırmanın olgu bilim (fenomenoloji) deseni kullanılmıştır. Veri toplama aracı olarak Artvin' in Arhavi ilçesinde bulunan Mençuna Şelalesini ziyaret edenlerle yarı yapılandırılmış görüşme yapılmıştır. Veriler araştırma ekibi tarafından yarı yapılandırılmış sorulardan oluşan görüşme formu aracılığı ile toplanmış ve içerik analizi ile yorumlanmıştır. Araştırma sonucunda bireylerin özçekim yaparken sosyal tatmin dürtüsü ile özçekim yaptıkları, özçekimin bir akım ve alışkanlık haline dönüştüğü, yalnızca sosyal medyada paylaşmak için değil ayrıca anı biriktirmek, sosyal albüm yapmak içinde özçekim yaptıkları, başkasından yardım istemeden herkesle aynı kare fotoğrafta görünmeyi sağladığı için özçekimin tercih edildiği, uygun şartlar olması durumunda kullanılan bir özellik olduğu, katılımcıların yalnızca özçekim yapmak için gezi yapmadıkları, anı yaşamanın gezinin temel amacı olduğunu, gezi öncesi özçekim yapmayı düşündükleri, özçekim yaparken özellikle doğal cazibe merkezlerinin çekicilik özelliğine göre arka fonda doğal bir görüntü olmasını istedikleri tespit edilmiştir.
\end{abstract}

Anahtar kelimeler: Özçekim, Motivasyon, Rekreasyon, Cazibe Merkezi

JEL Sinıflandırması: L83 


\begin{abstract}
It would not be wrong to say that with the development of technology and the emergence of social media, a process of social evolution has begun. This social evolution affects our photographs as well as our needs and social life. The selfies we take in daily life and the desire to share these in social media have started to shape our lives. From this point of view, the aim of this study is to explain selfie motivation of tourism attraction center visitors as a recreational activity. In this study, which is supported by literature, the phenomenology pattern of qualitative research is used in accordance with the aim of the research. Semi-structured interviews were conducted with those who visited Mençuna Waterfall in Arhavi district of Artvin as data collection tool. The data were collected by the research team through a interview form consisting semi-structured questions and interpreted with content analysis. As a result of the study, it was determined that the individuals took selfie with the urge of social satisfaction while taking selfie, selfie turned into a new trend and habit, the visitors took selfie not only to share on social media but also to save memories and create social albums, selfie is preferred because it allows to appear in the same frame in a photo with everyone without asking for help, selfie is a feature used in case of appropriate conditions, the participants did not only trip to take selfie, living the moment was the main purpose of the trip, they thought to take selfie before the trip, they wanted to have a natural image in the background especially according to the attraction feature of natural attraction centers.
\end{abstract}

Key words: Selfie, Motivation, Recreation, Attraction Center

JEL Classification: L83

\title{
GİRIŞ
}

Teknolojik gelişmeyle birlikte üretimin temel taşı olan insana ihtiyaç gittikçe azalmış, insanların iş dışı zamanlarında artış meydana gelmiştir (Karaküçük, 2016). Bu durum zamanla iş dışı zamanı değerlendirme ihtiyacını ortaya çıkarmış ve insanlar boş zamanlarını değerlendirme amacıyla çeşitli aktiviteler yapma arayışına girmiştir (Kurar ve Baltacı, 2014). İletişim teknolojilerinin günümüzdeki kadar gelişmediği y1llarda insanlar serbest zamanlarını farklı motivasyonlarla değerlendirmek için birbirlerine yaşadıkları deneyimleri yüz yüze görüştüklerinde anlatabilirken, iletişim teknolojilerindeki gelişmelerle başka insanların deneyimlerinden daha kolay haberdar olmaya başlamıştır (Aytaç, 2002). Böylece motivasyon kaynakları çeşitlenmiş, insanların motivasyon kaynakları araştırmalara konu olmuş ve 
insanları motive eden alanlar çeşitli teorilerle ifade edilmeye çalışılmıştır (Aydın ve Sezerel, 2017).

$\mathrm{Bu}$ teorilerden bir tanesi de "İtici-Çekici Faktörler" teorisidir (Kocabulut, 2016). Dann (1981) tarafından geliştirilen teoriye göre, cazibe merkezi ziyaretçileri, cazibe merkezini ziyarete ilişkin olarak çeşitli içsel uyaranlara maruz kalmaktadır. (Aktaran: Kocabulut, 2016). Bu uyaranlardan seyahat etmeye itenler itici faktörler olarak adlandırılırken, ziyaretçilerin istek ve ihtiyaçlarına cevap veren cazibe merkezi özellikleri, çekici faktörler olarak adlandırılmaktadır (Baloğlu. ve McCleary, 1999; Yoon ve Uysal, 2005'ten aktaran: Kocabulut, 2016).

Turistler, içsel ve dışsal faktörlerin etkisiyle seçim yaparken aynı cazibe merkezini ziyaret edebilecek potansiyeldeki turistlere kendi beğendikleri ve beğenmedikleri durumları anlatırken sosyal iletişim araçlarını sıkça kullanmaktadır (Uralman ve Genel, 2018). Günümüzde sosyal iletişim araçlarından yoğun kullanılanlardan biride sosyal medyadır (Öz, 2018). Sosyal medyada paylaşılan bir fotoğraf binlerce kelimelik sözlü tavsiyenin yapacağı etkiyi yapabilmektedir (Uzundumlu, 2015). Yaşanılan bu süreçler zamanla tüketim alışkanlıklarının değişmesine, temel tüketim ihtiyaçlarının yetersiz gelmesine etki etmiş, tüketimin şekli ve göstergesi önemli hale gelmeye başlamıştır (Azizağaoğlu ve Altunışık, 2012). Turistik tüketimin temelinde yaşanılan deneyimler bulunmaktadır (Harman ve Tan, 2018). Cazibe merkezine gezi amaçlı giden bir turist yaşadığ deneyimi çeşitli motivasyonel güdülerle ölümsüzleştirmek ve başka insanlara göstermek istemektedir (Satkın, 2017). Özellikle akılı telefonların gelişmesi, özçekimin kolaylığı, sosyal medya hesaplarının cep telefonlarına eklenmesiyle turistlerin yaşadıkları deneyimleri kolayca fotoğraflayıp paylaşma imkânı tanımaktadır (Uzun ve Uluçay, 2019). Bu durumun, sosyokültürel hayat üzerinde önemli etkileri bulunmaktadır (Agrawal, 2017'den aktaran: Harman ve Tan, 2018). Günümüz modern yaşamında tüketim, fayda sağlamaktan çok imaj yaratmak için yapılmaktadır (Azizağaoğlu ve Altunışık, 2012). Tüketimde sembolik unsurlar içeren duygusal faydalar öne çıkmaktadır (Altunışık ve Azizağaoğlu, 2012). Duygusal faydanın göstergelerinden bir tanesi özçekim tarzı fotoğraflardır (Atasoy Aktaş ve Bilgici Oğuz, 2018). Özçekim, bireyin kendi 
kendisini veya kendisini arkadaşlarıyla fotoğraflayıp bir sosyal medya mecrasında paylaşması demektir (Pösteki ve Velioğlu, 2014). İnsan özünde ağlamak, gülmek, üzülmek, sevinmek gibi değişik anlık duygular yaşar. Özçekim de birey kendini görmek istediği ve genellikle mutlu olduğu fotoğraflarını paylaşır (Oğuz ve Aktaş, 2018). Özçekim ile rekreatif aktiviteleri birleştiren nokta da burasıdır. İnsanlar rekreatif aktiviteler esnasında özgürce hareket ettiklerinden ve bu aktiviteler esnasinda sevdikleriyle beraber vakitlerini mutlu bir şekilde geçirdiklerinden, bu mutluluklarını fotoğraflarla ölümsüzleştirmek ve başka insanlarla bu fotoğrafları paylaşmak, mutlu anlarını insanlara göstermek istemektedir (Harman ve Tan, 2018). Bu durum cazibe merkezi pazarlamasına yön vermektedir. Özellikle özçekim de bireyler duruş, kıyafet ve arka plandaki görüntü ile insanlara bir ileti göndermektedir (Satkın, 2017). Bu ileti, diğer bireylerin sosyolojik ve psikolojik duygularında bir çağrışım uyandırır (Oğuz ve Aktaş, 2018). Tüm bunlardan yola çıkarak diyebiliriz ki, fotoğraflar, özellikle özçekim fotoğraflar, insanların tüketim alışkanlıklarına yön vermektedir ve insanlar boş zamanlarını planlarken diğer insanların özçekim fotoğraflarındaki göstergesel anlamdan etkilenmektedir (Azizağaoğlu ve Altunışık, 2012).

$\mathrm{Bu}$ çalışmada rekreatif amaçlı gezi yapan cazibe merkezi ziyaretçilerinin özçekim motivasyonları anlaşılmaya çalışılmıştır.

\section{YÖNTEM}

Nitel yöntemde yapılan bu araştırmada olgu bilim deseni kullanılmıştır. Olgu bilim (fenomenoloji) deseni, yaşantımızda farkında olduğumuz ancak tam olarak anlamlandıramadığımız olguları araştırmak için kullanılır (Yıldırım ve Şimşek, 2018).

\subsection{Araştırma Grubu}

Olgu bilim araştırmalarında bir deneyimi yaşayan ve yaşadığı deneyimi anlamlı bir şekilde anlatabilecek bireyler ya da gruplar veri kaynağını oluşturur (Yıldırım ve Şimşek, 2018). Araştırmanın veri kaynağını rekreatif amaçlı gezi yapan cazibe merkezi ziyaretçilerinin özçekim motivasyonlarına görüş bildirecek olan Artvin'in Arhavi ilçesindeki Mençuna Şelalesi cazibe 
merkezi bölgesine gelen ziyaretçiler oluşturmaktadır. Katılımcıların belirlenmesinde amaçlı örnekleme yöntemlerinden maksimum çeşitlilik örneklemesi kullanılmıştır.

Tablo 1. Katılımcıların demografik özellikleri

\begin{tabular}{ccccc}
\hline Kat1lımcı & Yaş & Cinsiyet & Eğitim Durumu & Memleket \\
\hline M1 & 42 & Kadın & Lise & Trabzon \\
M2 & 36 & Kadın & Yüksek Lisans & Düzce \\
M3 & 48 & Erkek & Yüksek Lisans & Trabzon \\
M4 & 23 & Kadın & Üniversite & İzmir \\
M5 & 75 & Erkek & İlk Ökul Mezunu & Trabzon \\
M6 & 34 & Erkek & Yüksek Lisans & Gaziantep \\
M7 & 44 & Kadın & Yüksek Lisans & Rize \\
M8 & 72 & Erkek & Yüksek Lisans & Trabzon \\
M9 & 39 & Erkek & Lisans & Rize \\
M10 & 45 & Erkek & Lisans & Trabzon \\
M11 & 40 & Kadın & Lisans & Ankara \\
M12 & 45 & Kadın & Yüksek Lisans & Ankara \\
M13 & 27 & Erkek & Ön Lisans & Artvin \\
M14 & 24 & Kadın & Lisans & Giresun \\
M15 & 23 & Kadın & Üniversite & Kocaeli \\
M16 & 34 & Erkek & Lisans & Sinop \\
M17 & 30 & Erkek & Lisans & Antalya \\
M18 & 43 & Kadın & Lisans & Düzce \\
M19 & 36 & Erkek & Yüksek Lisans & Artvin \\
M20 & 35 & Erkek & Lise & Sinop \\
M21 & 41 & Erkek & Lisans & Düzce \\
M22 & 26 & Kadın & Yüksek Lisans & Kayseri \\
\hline
\end{tabular}

\subsection{Veri Toplama Araçları}

Çalışmada veriler araştırma ekibi tarafından geliştirilen görüşme formu aracılığıyla toplanmıştır. Söz konusu görüşme formunun hazırlanmasında öncelikle daha önce benzer konularda yapılan çalışmalar taranmış sonrasında uzman görüşüne başvurulmuştur. Bu aşamadan sonra görüşme formu iki gönüllü üzerinde test edilmiş, araştırmanın amacı doğrultusunda düzeltmeler yapıldıktan sonra 2 bölüm ve toplam 9 sorudan oluşan nihai form elde edilmiştir. Formun ilk bölümü katılımcılara dair kişisel bilgiler, ikinci bölümde katılımcıların özçekime dair görüşlerini belirleyen sorular yer almaktadir. 


\subsection{Verilerin Toplanması}

Araştırmaya dâhil edilen bireylere kişisel bilgilerinin hiçbir suretle kullanılmayacağı, istedikleri takdirde görüşmenin sonlandırılabileceği, yapılacak görüşmenin yalnızca bilimsel amaçlı olarak kullanılacağı, görüşmelerin cep telefonu yardımıyla ses kaydı yapılacağı, sonrasında ses kayıtlarının analiz için yazılı doküman haline dönüştürüleceği ve analiz edileceği söylenmiştir. Görüşmeler Artvin İlinin Arhavi ilçesinde bulunan Mençuna Şelalesi cazibe merkezinde 2019 yılı Mayıs ayında hafta sonları yapılmıştır. Görüşmeler yapılırken güven ortamının oluşması için araştırmada katılımcıların gerçek isimlerinin kullanılmayacağı, bunun yerine Mençuna Şelalesinin baş harfi $(M)$ ve kaçıncı katılımcı olduğunu belirtir numara kullanılacağı söylenmiştir. Verilen cevaplar gerekli izinler alındıktan sonra cep telefonu yardımıyla ses kaydı yapılarak yazılı doküman haline dönüştürülmüş ve içerik analiziyle yorumlanmıştır.

\subsection{Verilerin Analizi}

Bir nitel araştırmada elde edilen verilerle yaşantılar ve algılar ortaya konmak isteniyorsa olgu bilim deseni kullanılmalıdır. Bu nitel araştırmada amaç Artvin Arhavi de bulunan Mençuna Şelalesi cazibe merkezini ziyarete gelenlerin özçekime yönelik algılarını ortaya koymak olduğu için olgu bilim deseni kullanılmış ve içerik analizi yapılmış, sonuçlar doğrudan katılımcı görüşlerine yer verilerek, ortaya çıkan kod ve temalar araştırma hedefleri doğrultusunda açıklanmış ve yorumlanmıştır. Artvin Arhavi de bulunan Mençuna Şelalesi cazibe merkezine ziyarete gelen ziyaretçilerle görüşmeler gerçekleştirilmiş ve özçekim yaptıkları alanlar durumlar gözlemlenmiştir.

\section{BULGULAR}

$\mathrm{Bu}$ bölümde araştırmanın amacı doğrultusunda elde edilen bulgulara yer verilmiştir. Yapılan içerik analizi neticesinde rekreatif bir etkinlik olarak turizm cazibe merkezi ziyaretçilerinin özçekim yapma motivasyonlarına dair ana tema, alt temalar ve kodlamalar bu bölümde yer almaktadır. 


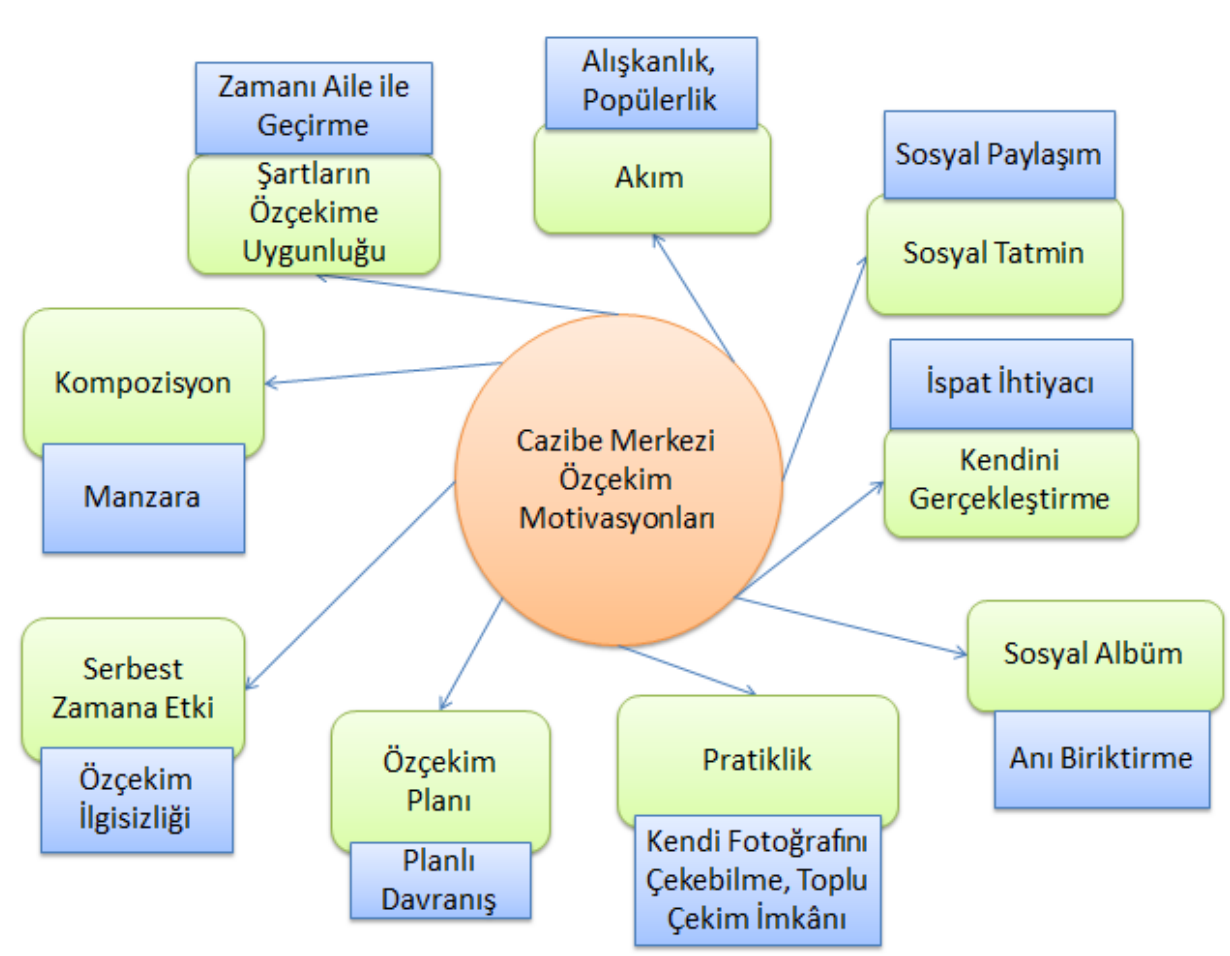

Grafik 1. Görüşme formu neticesinde elde edilen ana tema, alt temalar ve kodlamalar.

\section{1. “Cazibe Merkezi Özçekim Motivasyonları” Ana Temasına Dair Bulgular}

Katılımcılara "Cazibe Merkezi Özçekim Motivasyonları" ana temasında sorulan;

1) $\mathrm{Bu}$ cazibe merkezinde özçekim yaptınız mı? Neden? Yapmadıysanız neden?

2) Sizi özçekim yapmaya iten neden nedir? Neden böyle bir ihtiyaç hissettiniz?

3) $\mathrm{Bu}$ cazibe merkezinde yapılan özçekimin göstergesi (art anlamı) ne olmalidir?

4) Özçekim boş zamanlarınızı etkiliyor mu? Gezilerinize yön veriyor mu? Nas1l?

5) $\mathrm{Bu}$ cazibe merkezini ziyaret etme kararı verdiğinizde özçekim yapmayı planladınız mı? sorularına verilen cevaplar "Cazibe Merkezi Özçekim Motivasyonları" ana temasında şartların özçekime uygunluğu, akım, sosyal tatmin, kendini gerçekleştirme, sosyal albüm, pratiklik, özçekim planı, serbest zamana etki, kompozisyon alt temalarında zamanı aile ile 
geçirme, alışkanlı, popülerlik, sosyal paylaşım, ispat ihtiyacı, anı biriktirme, kendi fotoğrafinı çekebilme, toplu çekim imkanı, planlı davranış, özçekim ilgisizliği, manzara olarak kodlanarak aşă̆ıdaki tabloda açiklanmıştır.

Tablo 2. Cazibe merkezinde özçekim motivasyonlarına ait bulguları gösteren tablo.

\begin{tabular}{|c|c|c|c|}
\hline Ana Tema & Alt Temalar & $\begin{array}{l}\text { Görüşme Sonucu } \\
\text { Ortaya Çıkan Kodlar }\end{array}$ & Katılımcı \\
\hline \multirow{11}{*}{ 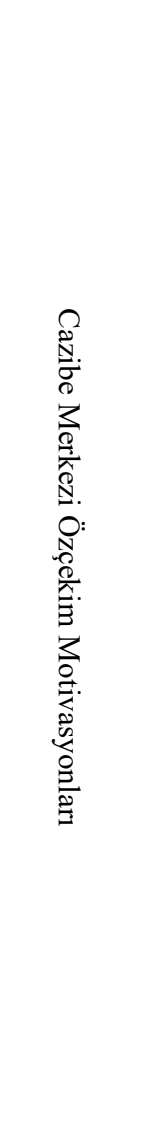 } & $\begin{array}{l}\text { Şartların Özçekime } \\
\text { Uygunluğu }\end{array}$ & $\begin{array}{l}\text { Zamanı Aile ile } \\
\text { Geçirme }\end{array}$ & $\begin{array}{c}\text { M6, M1, M19, M2, M6, } \\
\text { M7, M9 }\end{array}$ \\
\hline & \multirow{2}{*}{ Akım } & Alışkanlık & $\begin{array}{c}\text { M1, M16, M17, M18, } \\
\text { M19, M22 }\end{array}$ \\
\hline & & Popülerlik & M19, M6, M9 \\
\hline & Sosyal Tatmin & Sosyal Paylaşım & M11, M20, M17, M22, M9 \\
\hline & $\begin{array}{c}\text { Kendini } \\
\text { Gerçekleştirme }\end{array}$ & İspat İhtiyacı & $\begin{array}{c}\text { M12, M15, M2, M4, M6, } \\
\text { M8, M1, M11, M13, M14, } \\
\text { M16, M16, M19, M20, } \\
\text { M22 }\end{array}$ \\
\hline & Sosyal Albüm & Anı Biriktirme & $\begin{array}{l}\text { M14, M16, M6, M1, M16, } \\
\text { M4, M9, M13, M3, M3, } \\
\text { M6, M10, M18, M13, } \\
\text { M21, M10, M15, M14, M7 }\end{array}$ \\
\hline & \multirow{2}{*}{ Pratiklik } & $\begin{array}{l}\text { Kendi Fotoğrafinı } \\
\text { Çekebilme }\end{array}$ & $\begin{array}{c}\text { M16, M17, M19, M2, M6, } \\
\text { M19 }\end{array}$ \\
\hline & & Toplu Çekim İmkânı & M18, M21, M6 \\
\hline & Özçekim Planı & Planlı Davranış & $\begin{array}{l}\text { M19, M14, M10, M11, } \\
\text { M16, M20, M17, M13, } \\
\text { M22, M7, M6, }\end{array}$ \\
\hline & Serbest Zamana Etki & Özçekim İlgisizliği & $\begin{array}{l}\text { M3, M8, M2, M18, M6, } \\
\text { M9, M15, M13, M17, } \\
\text { M22, M12, M21, M10, } \\
\text { M15, M14, M8, M1 }\end{array}$ \\
\hline & Kompozisyon & Manzara & $\begin{array}{l}\text { M7, M10, M11, M12, } \\
\text { M17, M2, M20, M21, M3, } \\
\text { M3, M4, M5, M9 }\end{array}$ \\
\hline
\end{tabular}

Katılımcıların cazibe merkezi özçekim motivasyonlarına ait görüşleri "şartların özçekime uygunluğu, akım, sosyal tatmin, kendini gerçekleştirme, sosyal albüm, pratiklik, özçekim planı, serbest zamana etki, kompozisyon" alt temalarında, zamanı aile ile geçirme, alışkanlık, popülerlik, sosyal paylaşım, ispat ihtiyacı, anı biriktirme, kendi fotoğrafını çekebilme, toplu çekim imkânı, planlı davranış, özçekim ilgisizliği, manzara kodlamalarında 
değerlendirilmiştir. Zamanı aile ile geçirmeye yönelik olarak M2: " $B u$ anlamda iki tane çocuğum olduğu için çok zamanım olmuyor. Etkinlik yaptlkça özçekim yapmaya çalışlyorum." ve M1: “Ailemle gezmeyi seviyorum. $O$ anki gittiğiniz ortamda denk geliyorsa özçekim yapabiliyoruz. Şurada durayım da özçekim yapayım diye bir şey olmadı. " alışkanlığa yönelik olarak M17: "Özçekim hayatımıza girdi artık, moda oldu. Herhangi bir yere gezmeye gittiğimizde alışkanlık oldu, ihtiyaç oldu, bir stil oldu." ve M18: "Günümüzde artık her ortamda özçekim yapmak alışkanlık halini aldı." popülerliğe yönelik olarak M6: "Genel olarak sosyal medyada gördüğümüz, herkesin özçekime dönük bir çılgınlı̆̆ı var.” ve M9: “Özçekimin popüler olduğu zamanlarda, ilk çıtı̆̆g zamanlarda herkes gibi bizde denedik, özçekim yaptık." sosyal paylaşım olarak M9: "Aslında önceleri çektiğimiz fotoğrafları paylaşmıyorduk. Daha sonraları çektiğimiz fotoğrafların ve özçekimlerin sosyal medyada beğeni ve eleştiri almasinın bize mutluluk verdiğini fark ettik ve paylaşmaya başladık.” ve M17: “Özçekim yaptıktan sonra sosyal medyada paylaşlyoruz. Özçekim sosyal medyada paylaşmak için yapılır gibi hissediyorum." ispat ihtiyacı olarak M4: "Özçekim yapıp paylaşıyorum ben buradaydım demek için insanlara." ve M13 : "Insanlara biz buraya gitmiştik demek için çekip paylaşıyoruz." anı biriktirme olarak M16: "Bu nadir anları kaydedip arşivimize koyuyoruz ki ileriki yaşlarda büyük ihtimalle bunları çocuklarımıza, sevdiklerimize gösterip yad edeceğiz." ve M14: "Ileriki yıllarda bakmak için bir anı. Sevdiğim insan yanımdayken bir anı bırakmak." kendi fotoğrafinı çekebilme olarak M12: "Herkese fotoğrafimı çekin demektense her yerde kendi fotoğrafimı kendim çekiyorum." ve M19: "Birinci sebebi özçekimin kolaylığı. Başkasından rica etmeden kendi kendinizi bireysel ya da yanınızdaki kişi veya kişilerle birlikte fotoğraflayabiliyorsunuz. Yani kolay, hızl ve basit olması." toplu çekim imkânı olarak M18: "Toplu çekimlerde herkesin aynı karede bulunmasını sağlamak.” ve M21: "Özçekim yapmak için özel bir plan yapmadım ancak gördüğ̈̈m güzellikler karşısında fotoğraf çekmek ve yanımdaki herkesin aynı kare içerisinde olması isteği özçekim yapmayı kaçınılmaz kıldı." planlı davranış olarak M14: "Evet, özçekim yapmayı düşündüm. Sosyal medyada paylaşmak için özçekim yapmak geçti içimden." ve M19: "Evet düşündüm. Güzel bir kare yakalarsam yapabileceğim aklıma geldi." özçekim ilgisizliği olarak M3: "Başkasına fotoğraf çektiriyorum. Özçekim pek yapmıyorum." ve M8: "Ben hayatımda 4 defadan fazla özçekim yapmamışımdır." manzara olarak M17: "Özçekim de arka planda manzaralı bir görüntü olması önemlidir. Kendi görüntümüzün arka planında, doğadaki yeşil görüntü, deniz manzarası, şelale, akarsu arka planları fotoğrafa ferahlık katar." ve M3: 
"Şelale suyunun aklşkanlığı çok yüksek. Suların salınarak, kıvrılarak akması harika bir kompozisyon yaratıyor. Fotoğraf açısından güneş ışığı çok güzel, özellikle gün batımına doğru, sabaha karşı gün doğumuna doğru harika kareler çekilebilir." şeklinde görüş belirtmişlerdir.

\section{TARTIŞMA VE SONUÇ}

Cazibe merkezi ziyaretçilerinin yeni bir cazibe merkezini ziyaret ettiklerinde yaptıkları özçekimler, çektikleri fotoğraflar ve o fotoğraflardaki göstergesel anlam potansiyel ziyaretçiler için önem taşımaktadır. Yapılan araştırmalar görsel göstergelerin potansiyel ziyaretçileri etkilemede daha başarılı olduğunu ortaya koymaktadır. (Jaakonmaki, Müller ve Vom Brocke, 2017). İnsanlar bir cazibe merkezini ziyaret etmeye karar verme motivasyonlarını iletişim teknolojilerinin günümüzdeki kadar gelişmediği dönemlerde birbirlerine sözlü anlatırlardı (Ateşoğlu ve Bayraktar, 2011). İletişim teknolojisindeki gelişmeler sayesinde binlerce kelimenin yerini bir fotoğraf karesi alamaya başladı (Ergun, Bayrak ve Doğan, 2018). Bu fotoğraflardan biri de özçekim tarzı fotoğraflardır (Pösteki ve Velioğlu, 2014). Özçekim günümüzde sıkça kullandığımız, artık hayatımızın neredeyse bir parçası olan, insanın kendisini kendi kol mesafesiyle genelde cep telefonuyla çekip sosyal medya mecrasında paylaştığı bir fotoğraf türüdür (Özdemir, 2015). İnsanlar sosyal medya hesaplarında takipleştiği diğer kişilerin çektiği özçekimlerdeki gizil anlamdan etkilenmektedir (Öymen Kale, 2016). Bu araştırmada katılımcıların Arhavi Mençuna Şelalesi cazibe merkezini ziyaret ettikleri esnada özçekim motivasyonlarını açıklamaya çalışmaktadır.

Katılımcıların özçekim motivasyonları; Cazibe Merkezi Özçekim Motivasyonları" ana temasında şartların özçekime uygunluğu, akım, sosyal tatmin, kendini gerçekleştirme, sosyal albüm, pratiklik, özçekim planı, serbest zamana etki, kompozisyon alt temalarında zamanı aile ile geçirme, alışkanlık, popülerlik, sosyal paylaşım, ispat ihtiyacı, anı biriktirme, kendi fotoğrafinı çekebilme, toplu çekim imkânı, planlı davranış, özçekim ilgisizliği, manzara olarak kodlanarak toplanmıştır.

"Şartların Özçekime Uygunluğu" motivasyonunda katılımcılar: Özçekim için zaman ayırmak gerektiğini, özellikle çocuklu ailelerin özçekim yapacak vakit bulamadıklarını, çocuklardan fırsat kaldıkça özçekim 
yapabildiklerini, boş vakitlerine özçekimin bir yön vermediğini, güvenli ve olumlu şartların olması durumunda aile ile özçekim yaptıklarını ifade etmişlerdir.

Tam (2015), bireylerin yaş gruplarına göre özçekim paylaşımlarını konu alan yüksek lisans tezinde, 35 yaş ve üstü bireylerin özçekimi daha çok grup olarak yaptıklarını, özçekim yaptıkları grubun genellikle aile üyeleri olduğunu, çünkü 35 yaş ve üstü bireylerin aile üyeleriyle daha çok vakit geçirdiklerini, özçekimlerinin de bu doğrultuda aile üyeleriyle olduğu sonucunda varmıştır (Tam, 2015). Araştırmaya katılan bireylerin 39,18 yaş ortalamasına sahip olduğu görülmektedir. Şartların özçekime uygunluğu motivasyonunda belirtilen çocuklu ailelerin çocuklardan firsat buldukça özçekim yapabildikleri, güvenli ve olumlu şartların olması durumunda aile ile özçekim yaptıklarını vurgulaması, Tam (2015)'ın araştırma sonuçlarıyla paralellik gösterdiği görülmüştür. Açık alan cazibe merkezlerinin çocuklar ve büyükler için bazen tehlikeli olabileceği, özellikle yeni cazibe merkezlerinde güvenlik tedbirlerinin ve şartların tam anlamıyla sağlanamadığını, bu durumun da ziyaretçiler ve beraberindeki aile üyeleri için tehlike oluşturabildiği sonucuna varılmıştır.

“Akım” motivasyonunda katılımcılar: Özçekimin günümüzde bir akım haline dönüştügünü, anlık gelişen plansız bir davranış olduğunu, bende oradaydım demek için özçekim yaptıklarını, özçekim yapmak amacıyla bir yere gitmeseler de gittikleri yerlerde farklı bir manzara, bina, kültürel bir oyun veya farklı doğal bir yapı gördüklerinde özçekim yapma dürtüsü oluştuğunu söylemektedir.

Atasoy Aktaş ve Bilgici Oğuz'a (2018) göre; teknolojik gelişmeler sayesinde akıllı telefonların ve mobil internetin gelişimi, telefon pratikliğinin ve internetin mesaj ulaştırmadaki hızı, akıllı telefon kullanımının yaygınlaşması, bireylerin kendilerini sosyal platformlar üzerinde her zamankinden daha hızlı, sık, kolay ifade etmelerine olanak sağlaması, özçekimin bu denli popüler akım haline gelmesindeki en büyük etkenlerdendir. "Selfie" etiketi adı altında yapılan paylaşımların ortak noktası sosyalleşme, onay görme, iletişim kurma motivasyonları olduğunu belirtmiştir ve araştırma bulgularıyla paralellik göstermektedir. 
"Sosyal Tatmin" motivasyonunda katılımcilar: Gezdiklerinde güzel vakit geçirdiklerini başkalarının da görmesi istedikleri için özçekim paylaştıklarını, mutlu oldukları anların görünmesini istediklerini, gittikleri yerleri “ biz buraya gitmiştik” dürtüsüyle ölümsüzleştirip başkalarının görmesini istediklerini, paylaştıkları özçekimlerden takipçilerinin etkilenmesini istediklerini, sosyal medyadaki sosyal çevrelerinin bu fotoğrafları görmelerini istediklerini, paylaştıkları fotoğrafların sosyal medyada beğeni ve olumlu yorumların onları bir sonraki paylaşım için motive ettiklerini ifade etmişlerdir.

Çaycı ve arkadaşlarının (2019) yaptıkları araştırma; katılımcıların paylaştıkları özçekimlere yapılan beğeni ve yorumların özgüvenlerini arttırması ile firsatını bulduğunda gösteriş yapma arasında istatistiksel açıdan anlamlı bir ilişki olduğu sonucunu ortaya koymuştur. Başka bir ifadeyle; sosyal medya kullanıcılarının paylaştıkları iletilere yapılan yorumlar ve beğeniler onların özgüvenini arttırmaktadır ve bu durum onların gösteriş yapmasını sağlamaktadır. İnsanlar sevdikleriyle birlikte aktivite içindeyken mutludurlar ve bu mutluluklarını başka insanlara göstermek istemektedir. Çaycı ve arkadaşlarının (2019) yaptığı araştırma sonuçları, araştırmamıza katılan katılımcıların görüşleriyle ve araştırma sonuçlarıyla paralellik göstermektedir.

"Kendini Gerçekleştirme" motivasyonunda katılımcılar: Gördükleri güzel manzaralar karşısında özçekim yapmak ve manzarayı fotoğraflamak istedikleri, gezdikleri yerleri sosyal medya hesaplarında paylaşmak istedikleri, yaptığı paylaşımları diğer katılımcıların görmesi için bunu yaptıklarını aktarmışlardır.

Markwell (1997), fotoğrafların, seyahat sürecinde yer alan aktivitelerin ve seyahat süresince yaşanılan deneyimlerin kanıtlarını oluşturduğunu ifade etmektedir.

Kement ve Bükey (2019), gelişen teknolojinin getirdiği yenilikler ile birlikte bireyler farklı cazibe merkezlerine fotoğraf çekebilmek için seyahat etme motivasyonuna sahip olabilmektedir. Ayrıca gittikleri cazibe merkezinin sahip olduğu coğrafi özellikler veya bireylerin şahsi arzuları rekreasyonel motivasyon faktörlerinden olabilmektedir. Markwell ile Kement ve Bükey'in 
araştırma bulguları ile kendini gerçekleştirme boyutundaki bulgular birbiriyle paralellik göstermektedir.

"Sosyal Albüm" motivasyonunda kat1lımcılar: Gezdikleri yerlerde özçekim yaptıklarını, paylaşımların yıllar sonra çocukları veya kendinden küçüklere göstermek için yaptıklarını, hatıra-anı olarak kalması için de özçekim yaptıklarını, gezdikleri yerleri yıllar sonra tekrar gezdiklerinde sosyal medyadan daha önce paylaştıkları özçekimlere bakarak kendilerindeki ve gittikleri cazibe merkezlerindeki değişim hakkında değerlendirme yaptıklarını, doğal yapının gün geçtikçe azaldığını ve bu yapıları fotoğraflarla ölümsüzleştirmek istediklerini, sevdikleri insanlar yanlarındayken anı ölümsüzleştirmek istediklerini ifade etmişlerdir.

Şüphesiz ki fotoğrafın çekiliş amacı anı kaydetmektir ve bu davranışın altında o ana dair öykünün daha sonra hatırlanması vardır. Fotoğrafın anı ile olan ilişkisi sosyal ağlarda devam etmektedir. Sosyal ağlar kullanıcılarına istedikleri fotoğrafları paylaşabilecekleri ve istedikleri an hızlıca erişebilecekleri sanal depolama alanı sunmaktadır (Şener ve Özkoçak, 2013: 123-124 aktaran: Özdemir, 2015).

Şendeniz'e (2015) göre fotoğraf unutma ve yeniden hatırlama deneyimlerinin aracıdır. Yani fotoğrafın asıl amacı biriktirmek ve yıllar sonra aynı deneyimleri hatırlamaktır. Biriktirmenin ve daha çok paylaşmanın yapısı değişmiştir. Birey paylaşırken biriktirmekte ve bir açıdan biriktirmek için paylaşmaktadır.

Özdemir'e (2015) göre, dijital fotoğraf teknolojisinin gelişmediği, sosyal medyanın ortaya çıkmadığı dönemlerde insanlar anılarını hatırlamak, fotoğraf paylaşımı yapmak için bir araya gelirler, fotoğraf albümlerini çıkarırlar ve fotoğraflara bakarak anılarını yad ederlerdi. Dijital fotoğraf makinelerinin gelişimi, depolama alanlarındaki farklılaşmayla birlikte fotoğraf albümleri özel günlerde yakın akrabalara sunulan anı aracı olmaktan çıkıp gündelik bir hal almıştır. Şendeniz ve Özdemir'in çalışmasıyla araştırma sonuçlarından sosyal albüm motivasyonu paralellik göstermektedir.

"Pratiklik" motivasyonunda katılımcilar: Gezdikleri yerlerde fotoğraf çektirmek istediklerinde tanımadıkları kişilere " fotoğrafımı çeker misin" demektense özçekim ile kendi fotoğraflarını kendileri çektiklerini, özçekimin 
kolay ve hazır bir özellik olduğunu, fotoğraf çeken üçüncü kişiye nasıl çekmesi gerektiğini anlatana kadar kendi istediği kareyi yakaladığı an kontrolün kendisinde olduğunu ve istediği anı kendi fotoğraflayabildiğini, fotoğraf çektirecek birini bulamadıklarında herkesin aynı fotoğraf karesinde olduğu fotoğrafin özçekim olduğunu ifade etmişlerdir.

Uzundumlu'ya (2015) göre; İnsanlar sosyal medya öncesi dönemde sevdikleriyle bir cazibe merkezine gittiklerinde ve fotoğraf çekilmek istediklerinde, orada bulunan tanımadıkları birine "Fotoğrafımızı çekebilir misiniz?" demek zorunda kalır, makineyi karşıdaki kişiye verir, poz verip fotoğraf çektirirlerdi. Bu alışkanlık cep telefonlarının gelişmesi ile yavaş yavaş ortadan kalktı ve akıllı telefonu olan herkes başkasına ihtiyaç duymadan kendi kendine veya sevdikleriyle aynı karede olduğu fotoğrafları kolaylıkla çekmeye başlamıştır. Günümüzde kişinin akıllı telefon yardımıyla kendi kendisini fotoğraflayıp sosyal medya mecrasında paylaşmasına "Özçekim (Selfie)" denilmektedir.

Weiser (2015) çevrimiçi deneyimin önemli bir parçası haline gelen fotoğrafların akıllı cihazlar ile sosyal medyadaki dolaşımının son derece basit bir hale geldiğini söylemektedir (Aktaran: Oğuz, 2018).

Sosyal medya genel olarak kullanıcılara kendilerini sunmayı teşvik etmektedir. Kullanıcılar sosyal medyayı önemli ve özel görünmek, dikkat çekmek ve benlik saygısı kazanmak için kullandıklarını ifade etmektedirler. Kendilerine ait en cazip fotoğrafları seçerek onlardan beslenmeleri gerçekte onlara ait olmayan gerçek dışı bir görüntünün oluşmasına neden olmaktadır ve bunların tümünü cep telefonlarına eklenen uygulama sayesinde basit bir şekilde yapabilmektedir (Firestone, 2012'den aktaran: Oğuz, 2018). Bilgici Oğuz ve Atasoy Aktaş'ın (2018) yaptığı araştırma sonuçlarında; Selfie etiketi adı altında yapılan paylaşımların hepsinin ortak noktasının bireyin popüler olanın içinde yer alma, sosyal olarak kabul ve onay görme, sosyalleşme ve iletişim kurma motivasyonlarının payının oldukça büyük olduğu ve bu motivasyonları zorlanmadan, basit şekilde yaptıkları görülmektedir. Weiser, 2015; Oğuz, 2018; Bilgici Oğuz ve Atasoy Aktaş, 2018 ile Uzundumlu'nun (2015) çalışmalarıyla araştırma sonuçlarından olan pratiklik motivasyonundaki katılımcı görüşleri paralellik göstermektedir. 
“Özçekim Planı” motivasyonunda katılımcılar: Cazibe merkezi ziyaretçilerinin ziyaret kararı öncesi güzel bir manzara veya cazibe merkezinin özelliğine yönelik farklı bir yap1, doğal güzellik, çekicilik gördüklerinde özçekim yapmayı cazibe merkezine gelmeden önce planladıkları katılımcıların görüşlerinden anlaşılmaktadır.

"Serbest Zamana Etki” motivasyonunda ise, özçekim paylaşmak için pek vakit bulamadıklarını, özçekim yapmanın bazen programa uyumu bozduğunu, özçekim yaparken anı kaçırdıklarını, sadece özçekim yapmak için bir yere gitmek istemediklerini, gezinin asıl amacının doğayı gezmek görmek olduğunu, sık özçekim yapılması durumunda gezi amacının kıymetini yitirdiğini aktarmışlardır.

Uzun ve Uluçay'ın (2019) 3112 katılımcı üzerinde yaptığı araştırmada 1257 katılımcının özçekim paylaşmadığı, katılımcılar özçekim paylaşmama nedenlerini teknik ve zamansal nedenler, kendini korumaya yönelik nedenler, kamunun dikkatinden kaçınma ve örnek olma şeklinde ifade etmiştir. Yine Uzun ve Uluçay (2019) çalışmasında yer verdiği bir katılımcı görüşünde katılımcının "Ayrıca manzaranın veya olayın tadını çıkarmak varken neden sürekli fotoğraf çekinip belgeleyeyim ki? Kime neyi kanıtlıyorum?” (Uzun ve Uluçay, 2019). Şeklindeki ifadesi araştırma bulgularından serbest zamana etki motivasyonu ana temasındaki bulgularla paralellik göstermektedir.

"Kompozisyon" motivasyonunda katılımcılar: Doğal manzarayı arka fona alarak özçekim yaptıklarını, yeşilliklerin, doğal farklılıkların özçekim yaparken arka fonda olmasını istediklerini, ziyaret ettikleri doğal cazibe merkezine ait özelliğin ve doğallığın kendileri ile birlikte arka fonda görünmesini istediklerini, cazibe merkezlerinde oluşan doğal gök kuşağı, sis bulutu, çise gibi doğa olaylarını arka fona alarak fotoğraf çekmek istediklerini ve ışık kırılmalarına, yansımalarına önem verdiklerini söylemektedir.

Özhancı ve Yılmaz (2013) yaptığı görsel peyzaj analizinde, yüksek puana sahip görüntülere bakıldığında; yalnızca dağ görüntüsü olan görüntülerden ziyade doğal bitki çeşitliliğinin fazla olduğu görüntülerin tercih edildiği ortaya konmuştur. Ayrıca, doğal bitki çeşitliliği görüntüsüyle beraber beyaz kar örtüsünün fotoğrafa fazladan katkı sağlayan bir unsur olduğu görülmüştür. Dağ ve su manzarası olan görüntülerde ise; su durgun ve 
yansıtıc1 özelliğe sahipse görüntünün odağına suyun alındığı, dă̆ görüntüsünün ise arka fon olduğu görüntüler yüksek puan almıştır. Çalışmanın genlinde ise su olan görüntüler tüm görüntülerden daha fazla puan alarak en çok tercih edilen görüntü türü seçilmiştir (Özhancı ve Yılmaz, 2013). Özhanc1 ve Y1lmaz'ın (2013) araştırma bulgularıla kompozisyon motivasyonunda katılımcı görüşleri paralellik göstermektedir.

Ayrıca cazibe merkezine gelen ziyaretçilerin ister özçekim ister profesyonel fotoğraf makineleriyle çekim yapsınlar güvenle ve birbirlerine engel olmadan çekim yapabilecekleri alanlar oluşturulmalıdır. Gün boyu yapılan gözlemlerde ziyaretçilerin özçekim yaptığı ve yapabildiği az sayıda nokta olduğunu, genelde katılımcıların şelalenin akan suyunu arka plana aldıkları gözlemlenmiştir. Teknolojinin gelişmesiyle artık sosyal bir akım halini alan özçekim kazaları da beraberinde getirmektedir. Gazete ve televizyon haberlerinde sıkça özçekim yaparken yüksekten düşen veya kaza geçirerek hayatını kaybeden insanların haberlerini görmeye başladık. Bağcı ve arkadaşlarının 2018 yılında yaptığı "Türkiye de Özçekim Yaralanma ve Ölümleri” isimli çalışmada dünya genelinde doğal ortamlarda özçekim yaparken ölümlerin en başında yüksekten düşme gelirken ülkemizde ikinci sırada yer almaktadır (Bağcı ve arkadaşları, 2018). Mençuna Şelalesi cazibe merkezinin ıslak zemini, kayalık ve yüksek uçurumlardan oluşan yapısı nedeniyle cazibe merkezi ziyaretçilerinin bu şekilde kaza geçirmemeleri için gerekli güvelik önlemleri alınmalı ve olası kazaların önüne geçilmelidir. Yaşanacak olumsuz bir durum cazibe merkezi çekiciliğine zarar verecektir.

\section{KAYNAKLAR}

Ateşoğlu, İ ve Bayraktar, S. (2011). Ağızdan Ağıza Pazarlamanın Turistlerin Destinasyon Seçimindeki Etkisi. ZKÜ Sosyal Bilimler Dergisi, 14(7), 95-108. Aydın, S. ve Sezerel, H. (2017). Seyahat Motivasyonları Üzerine Bir Yazın İncelemesi, Nevşehir Hacı Bektaş Veli Üniversitesi SBE Dergisi, 7(2), 118140 .

Aytaç, Ö. (2002). Boş Zaman Üzerine Kuramsal Yaklaşımlar, Fırat Üniversitesi Sosyal Bilimler Dergisi, 12(1), 231-260.

Azizağaoğlu, A. ve Altunışık, R. (2012). Postmodernizm, Sembolik Tüketim ve Marka, Tüketici ve Tüketim Araştırmaları Dergisi, 4(2), 33-50. 
Bağcı, G., Pekşen, T.F., Askay, M., Aydoğdu, H.İ., Kırcı, G.S. ve Özer, E. (2018). Türkiye'de Özçekim Yaralanma ve Ölümleri. Klinik Tlp Aile Hekimliği Dergisi, 10(3), 33-35.

Can, E. (2015). Boş Zaman, Rekreasyon ve Etkinlik Turizmi İlişkisi, İstanbul Sosyal Bilimler Dergisi, 10(1), 1-17.

Çaycı, B., Çaycı, A. E. ve Eken, İ. (2019). Narsisizm ve Selfie Paylaşımı İlişkisi Üzerine Nicel Bir Araştırma, Akdeniz Üniversitesi İletişim Fakültesi Dergisi, 31, 60-88.

Güneş, A. (2012). Çağdaş Bir Çözümleme Yöntemi: Göstergebilim. e- Journal of New World Sciences Academy, 7(2), 32-43.

Harman, S. ve Tan, E. (2018). Turist Fotoğrafları ve Turizm Pazarlaması Açısından Önemi, Türk Turizm Araştırmaları Dergisi, 2(3), 1-9.

Jaakonmaki, R., Müller, O. and Von Brocke, J. (2017). The Impact of Content, Context, and Creator on User Engagement in Social Media Marketing, 50th Hawaii International Conference on System Sciences,

Karaküçük, S. ve Gürbüz, B. (2007). Rekreasyon ve kent(li)leşme. Ankara: Gazi Kitabevi.

Kocabulut, Ö. (2016). Akademisyenlerin Uluslararas1 Kongre Kat1lım Motivasyonlarının Tespiti, Seyahat ve Otel Işsletmeciliği Dergisi, 14(1), 48-58. Karaküçük, S. (2016). Rekreasyon bilimi. Ankara: Gazi Kitabevi.

Kurar, İ. ve Baltacı, F. (2014). Halkın Boş Zaman Değerlendirme Alışkanlıkları:Alanya Örneği, International Journal of Science Culture and Sport, 2, 39-52.

Kement, Ü ve Bükey, A. (2019). Doğa ve Kültür Fotoğrafçıllı̆ı Kapsamında Rekreasyonel Motivasyonun Demografik Özelliklere Göre İncelenmesi. Tourism \& Recreation Dergisi, 1(1), 23-30.

Oğuz, C. B. ve Aktaş, A. D. (2018). Selfie Paylaşma Sürecine Etkide Bulunan Motivasyonlar Üzerine Bir İnceleme, Anadolu Üniversitesi İletişim Fakültesi Uluslararası Hakemli Dergisi, 26(3), 82-100.

Oğuz, T. (2018). Görünür Olma Takıntısı: Selfie Yayınlama Davranışı ve Narsisizm. 16th International Symposium Communication in the Millenium, 56-70.

Özhancı, E. Ve Yılmaz, H. (2013). Değişik Peyzaj Karakterleri Barındıran Dağların, Foto Safari Amaçlı Görsel Peyzaj Analizi, Atatürk Üniversitesi Ziraat Fakültesi Dergisi, 44(1), 83-89.

Öz, A. (2018). Sosyal Medya Ortamında Gösteriş̧̧i Tüketim: Bir Uygulama (Basılmamı̧̧ Yüksek Lisans Tezi). Harran Üniversitesi, Şanlıurfa. 
Özdemir, Z. (2015). Sosyal Medyada Kimlik İnşasında Yeni Akım: Özçekim Kullanımı, Maltepe Üniversitesi İletişim Fakültesi Dergisi, 2(1), 112-131.

Öymen Kale, G. (2016). Marka İletişiminde İnstagram Kullanımı. The Turkish Online Journal of Design, Art and Communication, 6(2), 119-127.

Pösteki, N. ve Velioğlu, Ö. (2014). Bireyin Kendini Sunuş ve Konumlandırış Biçimindeki Dönüşüm: Selfie Kimlikler. I. Uluslararası İletişim Bilimleri ve Medya Araştırmaları Kongresi Bildiri Kitabı, 2(1), 1-20.

Satkın, M. B. (2017). Otoportreden Selfie' ye Bireyin Görsel Temsilinin Dönüşümü, Ordu Üniversitesi Sosyal Bilimler Araştırmaları Dergisi, 7(2), 297-306.

Şendeniz, Ö. (2015). Bakmak, Biriktirmek, Paylaşmak: Fotoğraf, Bellek ve Sosyal Medya İlişkisi, Karadeniz Teknik Üniversitesi İletişim Araştırmaları Dergisi, 5(2), 21-31.

Tam, M. S. (2015). Erving Goffman'ın Dramaturjik Kuramı Çerçevesinde Sosyal Medyada Selfie (Özçekim) Paylaşımları (Basılmamış Yüksek Lisans Tezi). Marmara Üniversitesi, İstanbul.

Uzundumlu, Ö. (2015). Bir İletşim Unsuru Olarak Sosyal Selfie Uygulamaları, Atatürk Illetişim Dergisi, 8(1), 227-248.

Uralman, N.H. ve Genel, Z. (2018). Pazarlama İletişiminde Selfie ile Yaratılan HiperGerçeklik, Anadolu Üniversitesi İletişim Bilimleri Fakültesi Uluslararası Hakemli Dergisi, 26(3), 342-358.

Uzun, K. ve Uluçay, D. M. (2019). Özçekim (Selfie) Fotoğrafları Sosyal Ağlarda Paylaşma ve Paylaşmama Nedenleri. Erciyes İletişim Dergisi, 6(2), 11211140.

Yıldırım, A. ve Şimşek, H. (2018). Sosyal bilimlerde nitel araştırma yöntemleri. Ankara: Seçkin Yayıncılık.

Yurcu, G., Kasalak, M. A. ve Akıncı, Z. (2018). Turistlerin Boş Zaman Motivasyonunu ve Tatminini Etkileyen Faktörler: Beldibi Örneği. Manas Sosyal Araştırmalar Dergisi, 7(2), 517-536. 